\title{
Predicting Distress in Islamic Banks: The Effectiveness of Capital Measures in CAMELS Framework
}

\author{
Zahid ur Rehman Khokher* and Syed Musa bin Syed Jaafar Alhabshi
}

\author{
Institute of Islamic Banking and Finance, International Islamic University Malaysia
}

\begin{abstract}
This study aims to identify key capital adequacy measures and other parameters that effectively predict distress in Islamic banks taking a panel of 65 banks from 13 countries between 2008-2017 using logistic regression model. The paper also intends to see whether simpler ratios perform better than more complex, risk weighted measures in predicting distress in these banks. A total of nine alternative capital and leverage indicators are used in the model that mainly rely on financial and accounting data, which are supplemented by the addition of market leverage for listed banks. In order to capture variability in cross country analysis and impact of economic conditions and shocks, the study also adds several macroeconomic indicators in the model. The results suggest that most of the standard CAMELS indicators are relevant for studying distress in Islamic banks. Further, it is shown that three other capital ratios - Tier 1, tangible common ratio and market leverage - are equally effective in studying Islamic bank failures. The findings, however, reflect that Basel III leverage ratio and other accounting-based ratios do not offer effective early warning signals of Islamic bank stress. Overall, equity based risk-weighted capital ratios offer a more robust framework of regulation and supervision in Islamic banks.
\end{abstract}

Keywords: Early Warning System, Leverage Ratio, Bank Failure, Basel III, CAMELS, Risk-Based Capital, Regulation, Islamic Banks, Emerging Markets.

\section{INTRODUCTION}

Despite increasing growth and importance of capital market and insurance sectors in last half century, banking sector remains dominant part of financial systems throughout the developing world in Asia, Africa, Middle East, Latin America and others. Banks, as financial intermediaries, play their role by extending credit to actors in the economy through maturity transformation (Turner, 2010) and producing financial claims while ensuring liquidity demands by the depositors are met on demand ((DeAngelo \& Stulz, 2014). They also play significant role in providing other ancillary services useful to society such as facilitating transfers, supporting local and international trade and providing other fee based services. Consequently, they play key role in the smooth running of the financial and economic systems where they operate, thus contributing to economic growth and well-being of the individuals and firms at large.

Due to this significant role of banks in the economy, banking authorities around the world ensure strong regulation and supervision of banking sector for several reasons: i) to protect individual depositors; ii) to maintain a reliable payment system; iii) to ensure a well-articulated money supply as a part of monetary stability; iv) to see that customers get required services at reasonable prices; v) to protect the customer rights

*Address correspondence to this author at the Institute of Islamic Banking and Finance, International Islamic University Malaysia; Tel: +6013-3514060; Fax: 603-61964053; E-mail: zaahid@gmail.com and interests when dealing with banks (Pappas, Izzeldin, \& Fuertes, 2016; Spong, 2000). Nevertheless, repeated banking crises since early twentieth century are a testimony that banking regulation and supervision is not sufficient to keep them from failing. Especially, during the global financial crisis of 2007-08, the colossal failure of many large, systemically important banks and other financial institutions demonstrated the damage such failures can bring to not only local financial systems and economies but also at the regional and global level. Many governments chose to offer loans as well as explicit and implicit guarantees for banks' creditors (depositors and subordinated debt holders) which helped the banks' management and shareholders to evade the responsibility, while the risks were effectively transferred to the respective governments and ultimately the tax payers - a phenomenon commonly expressed as 'privatizing the gains and socializing the losses' (Acharya, Gujral, Kulkarni, \& Hyun Song Shin, 2011; Berger, DeYoung, Flannery, Lee, \& Öztekin, 2008; KAZU, 2009). These failures had enormous implications on the macroeconomic stability, growth and employment in these countries. The experiences of bank failures and distress in the last decade and the profound repercussions such failures could have for the society,

\footnotetext{
${ }^{1}$ The range of these 'bail-outs' has been estimated quite differently. As an indication, Bloomberg's estimation on the cumulative "spending" by the US Federal Reserve (this includes asset purchases plus lending) was $\$ 7.77$ trillion. Another study finds that the total spending was actually over $\$ 29$ trillion. A Detailed Look at the Fed's Bailout by Funding Facility and Recipient, by James Felkerson, University of Missouri-Kansas City, Dec 2011.

http://www.levyinstitute.org/pubs/wp_698.pdf
} 
nevertheless, has renewed interest in the study of bank failures and the tools that can predict such catastrophic events.

Historically, banking regulators have used capital adequacy (CAR) ratio as the primary instrument in their toolkit to monitor the performance of their banks and as an early warning signal to take corrective supervisory action if a bank falls below the stipulated requirements (Mayes \& Stremmel, 2012). However, the size and scale of global financial crisis showed that CAR does not offer sufficient information to predict an impending distress in a banking institution due to, among others, financial innovation and off-balance sheet vehicles which allowed the banks to indulge in 'capital arbitrage' and increase the leverage 'without any limits' (Admati, 2016). Capital regulation based on risk-weighted assets encouraged innovation designed to circumvent regulatory requirements and shifted banks' focus away from their core economic functions (Blundell-wignall \& Atkinson, 2010). The global standard setter for banks, the Basel Committee on Banking Supervision (BCBS) responded to this issue with two key measures: $\mathrm{i})$ introducing a non-risk weighted leverage ratio as a 'backstop' to CAR, with the impact of off-balance sheet assets fully considered, and ii) stipulating two new standardised ratios for liquidity management, called Liquidity Coverage Ratio and Net Stable Funding Ratio. Accordingly, in addition to focusing on the predictive power of CAR for bank distress, the literature produced after the global financial crisis has also given consideration to the imposition of leverage ratio and its implications for banking supervision. Similarly, some literature also suggested several alternative ratios such as gross revenue ratio, tangible common equity ratio, base risk weight ratio etc. and claimed that these ratios offer better, or at least equivalent, predictive power on bank distress as the classical CAR (see section 2 for details).

The size of Islamic banking sector is now over USD 1,700 billion and it has shown tremendous, mostly double-digit growth in last two decades in important regions of the world including Asia, Middle East, Africa and Europe (International Monetary Fund, 2018). This sector has achieved market share of more than $15 \%$ of overall banking sector in over 12 jurisdictions (Islamic Financial Services board, 2018) with at least four countries having market share of over $50 \%$. At the individual institutional level, many Islamic banks have grown in size and complexity and have expanded beyond their border, at the regional and international level. Similarly, some of these large Islamic banks could have the status of domestic systemically important banks in the Basel III regime when applied by respective banking regulators (IFSB, 2015). Some possible examples of these banks are: Kuwait Finance House, Albaraka Bank, Dubai Islamic Bank, Islami Bank Bangladesh, Alrajhi Bank and Qatar Islamic Bank etc. Owing to differences in business model, operations and balance sheet structures, the underlying risk of Islamic banking products and services are different from conventional banks which can have financial stability implications for these markets (Beck, Demirgüç-kunt, \& Merrouchec, 2013; Hasan \& Dridi, 2011; IMF, 2017).

The growing significance of Islamic banks thus calls for attention on the appropriate toolkit to be used for their monitoring and supervision. Owning to several peculiarities in the balance sheet structure and associated Shari'ah rules, the global standard setting body for prudential regulation of Islamic finance, the Islamic Financial Services Board (IFSB) has issued over five standards and guidelines on various aspects of capital adequacy regulation with calculation methodology of CAR in Islamic banks, covering aspects such as appropriate Shari'ah compliant instruments to be considered as components of capital and changes to be made in credit, market and operational risk to calculate risk weights. Similarly, its latest capital adequacy standard IFSB-15 (IFSB, 2013) has explained the possible impact of smoothing practices and risk absorbency in profit sharing investment accounts (PSIA) on CAR and changes to be made in its calculation methodology. Similarly, it has provided preliminary guidance on the application of Basel Committee's leverage ratio on Islamic banks, which is being revised now.

However, there are only a few studies available in Islamic banking literature that have empirically tested the possible metrics that can serve as early warning indicator of distress in these banks. One reason of this phenomenon could be the relative stability as well as infancy of Islamic banking sector. Similarly, there have not been many outright liquidations of Islamic banks in past decade or so. Nevertheless, it will not be correct to state that Islamic banks have been totally immune to any financial distress as previous studies such as (Abou-El-Sood, 2015; Hasan \& Dridi, 2011; Pappas et al., 2016) have recorded. For example, some Islamic banks in various jurisdictions have faced challenges in meeting regulatory CAR, whereas some have been dissolved or their control has been taken by supervisors. Similarly, some have been merged or 
acquired by other banks due to financial difficulties. Many banks in Gull Cooperation Council (GCC) countries, including Islamic banks, were also granted state support, including deposit placement by the respective governments.

Accordingly, this study attempts to expand the literature on Islamic banks in a number of ways: First, contrary to studies on bank distress that mostly focus on economically advanced markets, this study takes comprehensive dataset of 65 banks from 13 countries between 2008-2017 representing emerging markets in the GCC, North Africa, Asia and Europe; Second, in addition to CAR, several other alternative ratios proposed in literature on conventional banks have been tested for their efficacy in predicting distress in Islamic banks; Third, over half of dataset includes publicly listed Islamic banks that permits the testing of market leverage as one of the potential ratios, which is not tested in other studies on Islamic banks; Fourth, a new ratio called "Islamic banking leverage" is proposed and examined that takes into account the risk absorbency feature of PSIA; and Fifth, it offers insights on the application of Basel III proposals on Islamic banks by testing their relevance and effectiveness for this sector. This guidance will help Islamic finance standard setters, bank regulators and Islamic banks in choosing the most appropriate tool of leverage regulation and early warning signal.

The remaining paper is structured as follows: Section 2 consists of literature review which briefly tracks the history of bank regulation and the importance of early warning signals. Section 3 gives an overview of empirical models used for predicting bank distress, proposes a criterion for identifying distress in Islamic banks and explicates unique aspects of potential distress determinants from Islamic banking perspective. Section 4 offers empirical analysis and suggests policy implications for Islamic bank regulation and broader application on banks operating in emerging markets. Section 5 concludes the paper with some closing remarks and suggests ways to extend the study.

\section{LITERATURE REVIEW}

\subsection{The History of Bank Regulation before Basel II and Role of Capital Regulation}

While the history of formal banks goes as far as four centuries, explicit application of capital rules for commercial banks only started in 1980s. Before the implementation of these formal rules, supervisors of banking sector used to gauge the appropriateness of capital levels as a rule of thumb (Estrella, Park, \& Peristiani, 2000). United States implemented capital rules in 1981, followed by introduction of Basel I in 1988 for 'internationally active banks'. This framework was further strengthened by the introduction of Base II in 2004 that required large, international banks to maintain capital against their credit, market and operational risk. Since then, it has become principal mechanism for banking sector regulatory and supervisory authorities for measuring the bank strength. The CAR is essentially a risk-adjusted ratio, which is expressed in percentage as bank's total capital to its risk weighted credit exposures (Berger et al., 2008; Spong, 2000). The main objective of the CAR is to offer a 'cushion' to the 'unexpected losses' and protect the bank's fund providers (depositors, lenders and investors). Thus, as a principle, a larger bank will need higher amount of capital than a small sized bank, whereas a high-risk bank will need higher capital than a bank with less risk, other things equal. ${ }^{2}$ The maintenance of minimum CAR by the banks thus helps to keep confidence of stakeholders in the strength and resilience of the banking system, which is a major policy objective of any banking-sector regulator or supervisor in the world.

Since different types of banking assets such as cash, financing, investments and other assets have different risk profiles, CAR primarily adjusts for assets that are less risky by allowing banks to "discount" lower-risk assets. For example, government debt instruments (treasury bills, domestic government bonds) are allowed a 0\% "risk weighting" - that is, they are subtracted (or excluded) from total assets for calculating the CAR (Admati, DeMarzo, Hellwig, \& Pfleiderer, 2012; Hildebrand, 2008; Spong, 2000).

However, despite the implementation of CAR regime in most of the countries in 1990s and first decade of the new century, it could not provide a strong mechanism for absorbing the losses for several reasons. For example, in addition to considering common equity as a part of capital, Basel II permitted the banks to use hybrid debt capital instruments (such as long-term preferred shares, perpetual debt instruments, convertible debt instruments etc.) and subordinated term debt as a part of capital, despite

${ }^{2}$ For 'expected' losses, a provisioning regime is followed by banking institutions. 
acknowledging the fact that "subordinated term debt instruments have significant deficiencies as constituents of capital in view of their fixed maturity and inability to absorb losses except in a liquidation". ${ }^{3}$ The use of borrowed funds in the form of debt based instruments - such as subordinated term debt and hybrid capital - allowed the banks to further leverage their balance sheets in the calculation of regulatory capital calculations where most of their balance sheets were already heavily leveraged due to the use of customer and interbank deposits on the liability side. Under pressure from shareholders to increase returns, banks relied heavily on these debt-based instruments and operated with minimal equity, leaving them vulnerable if things went wrong. As an example, during 2000-2008 period, the world's largest 21 banks raised a total capital of USD 1.76 trillion, in which USD 1.64 trillion $(93 \%)$ of capital was raised in the form of debt (Acharya et al., 2011).

The use of high leverage in large conventional banks had enormous implications for the global financial system during the 2007-2008 global financial crisis. When these banks were hit hard with the losses and their equity was evaporated, instead of passing on the losses to the holders of these capital instruments, the governments in the crisis countries chose to 'bailout' these banks by bearing the risks themselves (effectively transferring it to the tax payers) for the fear of contagion due to the failure of too-big-to-fail financial institutions. (Acharya, Mehran, \& Thakor, 2015; Admati, 2016). Similarly, the risk weighting of the assets permitted the banks to design innovation aimed at evading the CAR and shifting the focus of banks away from undertaking key business function. Such products, as well as use of off-balance sheet vehicles, resecuritisation, money market funds etc. allowed the banks to indulge in 'capital arbitrage' and increase the leverage 'without any limits'. Thus, an unintended consequence of Basel II was its contribution to, or even reinforcement of adverse systemic shocks that materialized during the global financial crisis of 200708 (Admati, 2016). Capital regulation based on riskweighted assets encouraged innovation designed to circumvent regulatory requirements and shifted banks' focus away from their core economic functions (Blundell-wignall \& Atkinson, 2010). These financial

${ }^{3}$ Para 49(xii) of Basel II, 2006 version. Basel Committee on Banking Supervision. https://www. bis.org/publ/bcbs128.htm innovations also helped amplifying the banks' assetliability mismatch and risk to funding liquidity (D'Hulster, 2009; Wissén, 2010).

Another different, but closely associated, criticism on capital regulation was that risk-based measures, especially the use of internal models by the banks, are costly to implement and challenging to supervise Therefore, a number of studies around the global financial crisis suggested the use of 'simpler' ratios that could be effective in predicting the vulnerability in banking institutions such as leverage ratio (Estrella et al., 2000; Haldane, 2012)..

\subsection{Capital Reforms Introduced by Basel III}

(Hildebrand, 2008) mentions that from historical perspective, before the introduction of risk weight sensitivity in assets by the Basel I Accord in 1998, most countries used to apply simple leverage ratios. Some countries such as Canada, United States and Switzerland have been applying an unweighted leverage ratio since many decades before the financial crisis (Bordeleau, Crawford, \& Graham, 2009; D'Hulster, 2009; Gambacorta \& Karmakar, 2016; Kamada \& Nasu, 2010).

Hence, in order to respond to the lessons learned during the global financial crisis and replicating the experience of aforementioned countries, a number of studies by the BCBS as well as other bodies recommended the introduction of leverage ratio to resolve the problem of excessive leverage in the financial system (BCBS, 2010a; Bordeleau et al., 2009; Hildebrand, 2008; Kellermann \& Schlag, 2013). Consequently, when the BCBS introduced the reform package of global financial regulation in December 2010, commonly known as Basel III, it introduced the leverage ratio as a "backstop" measure to support the risk-based capital regulations that stipulate CAR. This new leverage ratio was aimed to constrain the build-up of leverage in the banking sector and to help avoid destabilizing deleveraging processes which can damage the broader financial system and the economy (BCBS, 2010b). This ratio, as defined by the Basel Committee is an un-weighted measure and calculated as Tier 1 capital to on-and off-balance sheet exposure i.e. an economic leverage, with a minimum value of $3 \%$.

The interest in the introduction of leverage ratio led to the introduction of vast literature which made an effort to investigate various aspects of the proposed 
ratio, its relative robustness as a capital measure and interaction with other ratios. ${ }^{4}$ For example, these studies look at the objective of regulating the financial sector and see how far leverage ratio fits into this objective? (Admati, DeMarzo, Hellwig, \& Pfleiderer, 2010; Atkinson \& Blundell-Wignall, 2010; Blum, 2008; Blundell-Wignall \& Caroline Roulet, 2013; Brei \& Gambacorta, 2014; Demirguc-Kunt, Detragiache, \& Merrouche, 2010; Estrella et al., 2000; Haldane, 2012; Kellermann \& Schlag, 2013; Merrouche, Detragiache, \& Merrouche, 2010; Ojo, 2015).

On the other hand, (Atkinson \& Blundell-Wignall, 2010; Demirguc-Kunt et al., 2010; Estrella et al., 2000; Haldane, 2012; Kellermann \& Schlag, 2013) investigate the interaction between the leverage ratio and CAR and give their findings on the simultaneous implementation of both ratios vis-à-vis the application of either of the two ratios.

More importantly, several studies on conventional banks questioned the use of leverage ratio as a secondary measure and noticed that leverage ratio (as well as some other measures) is a better measure, or at least of similar value, as CAR in gauging banks' strength and predicting their distress in the future. Similarly, it is easy and less costly to implement. Therefore, these studies suggest that this ratio should be given equal importance in the bank regulation, instead of using it only as a "backstop" measure as suggested by the BCBS (Blundell-wignall \& Atkinson, 2010; Buehler, J., \& Samandari, 2010; Haldane, 2012).

Contrary to the above studies where arguments are presented in favour of implementing leverage ratio as an additional requirement to capital ratios, some researchers have found contradicting results that show that it is not effective in all the cases. These include: (Pratomo \& Ismail, 2007) for Malaysian banks, (Kellermann \& Schlag, 2013) for Swiss banks and by (DeAngelo \& Stulz, 2014) for US banks.

\subsection{The Need for Early Warning Systems on Bank Distress}

Due to the significance of banking sector to the financial systems, the literature on bank distress and its prediction models has been produced in large

\footnotetext{
${ }^{4}$ While most studies quoted here were conducted after the introduction of Leverage Ratio as a part of Basel III package in 2009-2010 that is applicable at the global level, some papers mentioned here were undertaken prior to this period as some regulatory authorities such as those in US, Canada and Switzerland have a Leverage Ratio based capital regime since 1990s.
}

numbers. However, availability of reliable data remains a challenge in many developing markets and therefore, most research has been dedicated to either US, EU or other advanced markets. (Mayes \& Stremmel, 2012) tracks about 40 such studies, over 35 of which have been conducted for advanced markets.

Central banks and bank supervisors use a range of on- and off-site surveillance tools to track the performance and stability of banking institutions. (Chernykh \& Cole, 2015; Poghosyan \& Čihák, 2011). Banks are required to maintain capital at "minimum acceptable level" as well as adequate level of capital ratio (Estrella et al., 2000). Similarly, both Basel II and Basel III have made a distinction in capital for going concern and gone concern capital, commonly known as Tier 1 and Tier 2 capital. This distinction is important since net worth of the bank reduces sharply when it is in distress and close to becoming a gone concern. Therefore, regulators have a reason to select a capital ratio that is closely correlated with the bank distress i.e. the ratio should exhibit a relationship with high failure probability of the bank. Accordingly, bank supervisors have devised various early warning systems and linked them with various levels of capital as well as other indicators of bank performance. In practical terms, however, all distress events are unique. Nevertheless, the main job of prediction models is to search for some patters which can be associated with bank distress with reasonable accuracy. The challenge is that over time, banks understand how their vulnerability is being monitored by regulators, which leads them to "massage the respective ratios" while still keeping the business as usual (Estrella et al., 2000). The continuous change in response poses challenges on the prediction quality of these models which require the need for continuous improvement and adjustments.

\subsection{Models for Predicting Bank Distress}

One of the earliest bank distress models was developed by the US in late 1970s by the Federal Deposit Insurance Corporation (FDIC) called CAMELS model. This model monitored several key aspects of bank performance such as financial, operational and managerial quality. Thus, it included dimensions of: capital adequacy $(C)$, asset quality $(A)$, management quality $(M)$, earning power $(E)$, liquidity $(L)$ and sensitivity to market risk (S), the last of which was introduced in 1996 after Basel II. Interestingly, despite being one of the earliest models, CAMELS is still widely used both in practice by the bank supervisors and in academia for accessing the bank distress. Some 
papers added macroeconomic variables such as GDP growth, credit growth, inflation, interest rates and exchange rates. Similarly, some researches have chosen to use market information, such as risk (return volatility), share prices and bond spreads ((Mayes \& Stremmel, 2012).

Most studies have used "survival models" to measure the hazard of distress or failure in banks. Survival models are of two types, where first type of model is called Pobit or logit models which predict the exit, failure, survival or loss of one entity i.e. do or die model. Both approaches use statistical estimation techniques such as maximum likelihood that offer better estimation than linear estimation methodologies. However, they have different assumptions about the distribution of data: The logit model considers a logistic distribution whereas probit model presumes a standardised normal distribution. The second type of model is called hazard or duration models which predicts the duration of entity's existence starting from entry to exit i.e. when and how long will the entity survive. These models are also termed as survival time analysis. The more dominant of this model is Cox proportional hazard model (Mayes \& Stremmel, 2012; Pappas et al., 2016).

More recently, with the availability of more data and advanced processing power, some new non-statistical techniques have been developed for predicting bank distress. These include: artificial neural networks which make use of non-linear data. Similarly, data development analysis uses liner programming technique and non-parametric approach to benchmark banks with certain qualities. Moreover, some nonparametric techniques such as Kaplan-Mier estimator of survival function have been used in literature (Pappas et al., 2016). Another quite popular method in literature to study the soundness of firms is z-score as it is inversely proportional to the probability of a firm's insolvency (Čihák \& Hesse, 2010).

\subsection{Empirical Literature on Capital Ratios in Conventional and Islamic Banks}

One of the earlier studies, conducted before the global financial crisis, was undertaken by (Estrella et al., 2000). Using a data set of 62,000 observations for failed and surviving banks in US over a five-year period (1988-1992), they have tested three ratios for their analysis using both proportional hazard model and logit regression: risk weighted CAR, leverage ratio and gross revenue ratio. The study finds that for the long term, risk weighted CAR is the most effective predicator of bank failure. However, for a short horizon of less than two years, other two measures provide equally useful information.

The comparison between the implications of various capital ratios got further attention in the academic literature after the financial crisis when international bodies such as G-20 and the Basel Committee announced the introduction of Leverage Ratio as a part of global regulatory reforms.

One of first such studies was undertaken by (Blum, 2008) who focused on the reporting aspects of regulatory capital ratios. Using a theoretical model, they observed that if supervisors have a limited ability to identify or to sanction dishonest banks in their reporting of risk-based capital (CAR), a riskindependent leverage ratio restriction may be necessary to induce truthful risk reporting as risky banks have an incentive to underestimate their risks. They also observe that leverage ratio can work as a safeguard against potential shortcomings of risksensitive requirements, notably regulatory arbitrage and problem of validation.

The information value of the capital ratios to the equity holders is studied by (Demirguc-Kunt et al., 2010), who observed that during the global financial crisis, stock returns were relatively more sensitive to leverage ratio that the CAR. They study the impact of various levels of capital - such as Basel's total CAR, Tier 1 capital ratio, Tier 2 capital ratio, common equity ratio and leverage ratio - on the stock returns. For analysis of panel data, the study tests an empirical model on 381 conventional banks in 12 economies during the period Q1 of 2005 to Q1 of 2009. All banks are from advance economies. In their model, taking banks' stock returns as dependent variable, where independent variables include bank capital, bankspecific variables (such as P/E ratio, loan loss provisions, liquid assets, total deposits, net loans etc.) and some dummy variables.

Another significant study on this subject was performed by (Haldane, 2012) of Bank of England who made a comparison of the performance of two measures of capital in predicting bank failure using logit regression and proportional hazard model using US bank data, namely Tier 1 regulatory capital ratios and simple leverage ratio. The study finds that Leverage Ratio is better predictor of bank distress for large banks, whereas for small regional banks, Tier 1 shows more robust results. 
(Blundell-wignall \& Atkinson, 2010) compare the write-downs and credit losses from banks in OECD countries (excluding US) during the financial crisis (accumulated from January 2007 until mid-2009) in reference to two measures: a) Tier 1 capital ratios; and b) leverage ratio (Common equity/total assets). Their comparison found that higher Tier 1 ratio was closely associated with bigger losses of these banks on a cumulated basis during the crisis. On the contrary, they found that simple leverage ratio has an inverse relationship with the losses experienced by the banks during the financial crisis of 2007-08. Thus, they argue, that leverage ratio is a better measure of gauging the potential credit risk a bank could experience in distressed market conditions.

Similarly, (Blundell-Wignall \& Caroline Roulet, 2013) study models on the distance-to-default and conduct a multivariate regression analysis of a panel of 94 banks over a period 2004-2011. They compare Basel Tier 1 ratio with the leverage ratio in order to identify which measure is better predictor of time to default. They control the data for each bank's market beta which included housing prices, size, leverage, trading assets, wholesale funding and cross border revenue. Overall, the study found that leverage ratio is much better predictor of default risk than the Tier 1 capital ratio.

For Islamic banks, the studies on this subject have been quite limited. (Čihák \& Hesse, 2010) compared the relative strength of Islamic and conventional banks used z-score as a measure of bank soundness. Zscore. They empirically test the data from 77 Islamic bank and 397 conventional banks from 18 jurisdictions for 1993-2004 period. Along with using basic financial ratios, to control for asset size, composition of assets, cost efficiency, market concentration as well as macroeconomic cycles, they add several variables in the model such as: asset size, loan to assets ratio, cost to income ratio, Herfindahl index, GDP growth, inflation rate and currency depreciation. Their results showed that small Islamic banks have stronger performance than their peers, whereas for large Islamic banks, their conventional peers are financially stronger. Similarly, smaller Islamic banks are more stronger financially from the large Islamic banks due possibly to the credit risk management weaknesses in the large banks.

(Pappas et al., 2016) studied the hazard of failure in Islamic and conventional commercial banks using nonparametric Kalpan-Mier estimator as well as Cox proportional hazard model. The study took sample of 421 banks in the Middle East, Africa and Asia between 1995 to 2010 with 106 Islamic banks and 315 conventional banks. Using a range of accounting ratios and macroeconomic variables, the paper observed that higher leverage increases the failure risk of conventional banks whereas the effect is instead favourable for Islamic banks. At macroeconomic level, a relevant finding for policymakers is that failure risk is more strongly driven by macroeconomic factors such as inflation for Islamic banks. Their analysis also suggests that Islamic banks have lower failure risk and are less interconnected which reduces the likelihood of domestic co-failure.

In last three years, however, quite a number of papers have been published using different prediction models of Islamic banks, sometimes in comparison with conventional banks. The summary of these studies is provided in the Table below.

The publication of above literature on the resilience of Islamic banking and prediction models for distress is quite valuable for understanding the dynamics of this fast-growing industry. A common factor that can be noticed in these papers is the use of various alternative ratios complementing the CAMEL framework, though last element sensitivity against market risk (S) has not been studied by most studies. Since outright failures of Islamic banks failures are quite limited, most studies don't have any distressed bank in their sample data. Similarly, only a few studies have taken a global data of Islamic banks and instead selected a sample at their national level only. It can be also observed that no study has used market-based indicators such as market leverage in the model. The use of macroeconomic variables is also limited to a few papers. Most importantly, no study has covered the impact of alternative capital ratios proposed by Basel III or other significant studies on this subject and their possible implications on the regulation and supervision of Islamic banks.

\section{MODEL FORMULATION AND DATA}

\subsection{Research Objective and Methodology}

Key objective of this paper is to study the effectiveness of capital ratios and other parameters in predicting distress in Islamic banks. In order to study the robustness of various capital and leverage ratios as other stability indicators, this paper will use logit survival model and test the predictive power of various ratios for the failure of Islamic banks. A number of studies cited in this dissertation have used this technique such as (Aliyu \& Yusof, 2017; Estrella et al., 
Table 1: Overview of Literature on Failure/Distress in Islamic Banks

\begin{tabular}{|c|c|c|c|c|c|c|c|c|}
\hline Authors & Model & Period & \# of Banks & $\begin{array}{c}\text { Failed/ } \\
\text { Distressed } \\
\text { Banks }\end{array}$ & Region & $\begin{array}{c}\text { Variables } \\
\text { Used }\end{array}$ & $\begin{array}{l}\text { Macroeconomic } \\
\text { Variables }\end{array}$ & Key Results \\
\hline $\begin{array}{c}\text { (Pappas et al., } \\
\text { 2016) }\end{array}$ & $\begin{array}{l}\text { Logit \& } \\
\text { Hazard } \\
\text { Model }\end{array}$ & $\begin{array}{l}1995- \\
2010\end{array}$ & $\begin{array}{c}106 \text { Islamic } \\
315 \\
\text { Conventional }\end{array}$ & $\begin{array}{c}8 \text { Islamic } \\
89 \\
\text { Conventional }\end{array}$ & $\begin{array}{l}18 \text { Muslim } \\
\text { Countries }\end{array}$ & 24 & $\begin{array}{l}\text { GDP growth, } \\
\text { Inflation, FX } \\
\text { depreciation, bank } \\
\text { concentration, } \\
\text { Islamic banking } \\
\text { share, sovereign } \\
\text { rating }\end{array}$ & $\begin{array}{c}\text { Higher } \\
\text { leverage and } \\
\text { higher liquidity } \\
\text { decrease } \\
\text { failure risk in } \\
\text { sample banks. }\end{array}$ \\
\hline $\begin{array}{c}\text { (Budiman, } \\
\text { Herwany, \& } \\
\text { Kristanti, 2017) }\end{array}$ & Z-score & $\begin{array}{l}2011- \\
2015\end{array}$ & $\begin{array}{l}11 \text { Islamic } \\
\text { banks }\end{array}$ & Nil & Indonesia & 6 & NIL & $\begin{array}{l}\text { No distress in } \\
\text { any bank. }\end{array}$ \\
\hline $\begin{array}{c}\text { (Sapuan, Bakar, } \\
\text { \& Ramlan, } \\
\text { 2017) }\end{array}$ & $\begin{array}{l}\text { Neural } \\
\text { Network }\end{array}$ & $\begin{array}{l}2005- \\
2014\end{array}$ & $\begin{array}{l}16 \text { Islamic } \\
\text { banks }\end{array}$ & Nil & Malaysia & 3 & NIL & $\begin{array}{l}\text { Credit risk is } \\
\text { the main } \\
\text { predictor of } \\
\text { distress. }\end{array}$ \\
\hline $\begin{array}{l}\text { (Halteh, Kumar, } \\
\text { \& Gepp, 2018) }\end{array}$ & $\begin{array}{l}\text { Stochastic } \\
\text { Model, } \\
\text { Altman Z- } \\
\text { Score }\end{array}$ & 2014 & $\begin{array}{l}101 \text { Islamic } \\
\text { banks }\end{array}$ & Nil & $\begin{array}{l}\text { Islamic } \\
\text { Countries }\end{array}$ & 18 & NIL & $\begin{array}{l}\text { Working } \\
\text { Capital/Total } \\
\text { Assets and } \\
\text { Return on } \\
\text { Revenue are } \\
\text { the most } \\
\text { significant } \\
\text { predictors of } \\
\text { distress. }\end{array}$ \\
\hline $\begin{array}{c}\text { (Kumar \& } \\
\text { Sayani, 2015) }\end{array}$ & Z-score & $\begin{array}{l}2008- \\
2014\end{array}$ & $\begin{array}{l}11 \text { Listed } \\
\text { Islamic Banks }\end{array}$ & Nil & $\begin{array}{l}5 \text { GCC } \\
\text { Countries }\end{array}$ & 7 & NIL & $\begin{array}{l}\text { All sample } \\
\text { banks were } \\
\text { resilient. } \\
\text { Earning ability } \\
\text { remains a } \\
\text { challenge. }\end{array}$ \\
\hline $\begin{array}{c}\text { (Aliyu \& Yusof, } \\
\text { 2017) }\end{array}$ & $\begin{array}{c}\text { Logit \& } \\
\text { Hazard } \\
\text { Model }\end{array}$ & $\begin{array}{l}1987- \\
2014\end{array}$ & $\begin{array}{l}170 \text { Islamic } \\
\text { Banks }\end{array}$ & 28 Banks & $\begin{array}{l}24 \text { mainly } \\
\text { Muslim } \\
\text { Countries }\end{array}$ & 12 & $\begin{array}{l}\text { Inflation, GDP per } \\
\text { capita. }\end{array}$ & $\begin{array}{c}\text { Capital, } \\
\text { managerial } \\
\text { efficiency and } \\
\text { liquidity are the } \\
\text { major } \\
\text { determinants. }\end{array}$ \\
\hline $\begin{array}{c}\text { (Abdul Rahman } \\
\text { \& Masngut, } \\
\text { 2014) }\end{array}$ & $\begin{array}{l}\text { Neural } \\
\text { Network }\end{array}$ & $\begin{array}{l}2006- \\
2010\end{array}$ & $\begin{array}{l}17 \text { Islamic } \\
\text { banks }\end{array}$ & Nil & Malaysia & 6 & NIL & $\begin{array}{l}\text { All sample } \\
\text { banks were } \\
\text { resilient }\end{array}$ \\
\hline (Khan, 2016) & $\begin{array}{c}\text { Altman Z- } \\
\text { Score, O- } \\
\text { Score, } \\
\text { Logit }\end{array}$ & $\begin{array}{l}2009- \\
2015\end{array}$ & $\begin{array}{l}40 \text { Listed } \\
\text { Financial } \\
\text { Firms }\end{array}$ & 20 Firms & Pakistan & 10 & NIL & $\begin{array}{l}\text { Logit model is } \\
\text { most effective. } \\
\text { Retained } \\
\text { earnings, } \\
\text { profitability and } \\
\text { liquidity } \\
\text { (current } \\
\text { liabilities) are } \\
\text { key } \\
\text { determinants of } \\
\text { distress. }\end{array}$ \\
\hline $\begin{array}{c}\text { (Anwar \& Ali, } \\
\text { 2018) }\end{array}$ & $\begin{array}{l}\text { Artificial } \\
\text { Neural } \\
\text { Networks }\end{array}$ & $\begin{array}{c}\text { Jan } \\
2013- \\
\text { Feb } \\
2015\end{array}$ & $\begin{array}{c}1 \text { bank (Bank } \\
\text { Syariah } \\
\text { Mandiri) }\end{array}$ & Nil & Indonesia & 14 & $\begin{array}{l}\text { Exchange rate, } \\
\text { inflation rate, } \\
\text { interest rate }\end{array}$ & $\begin{array}{c}11 \text { out of } 14 \\
\text { variables are } \\
\text { significant. }\end{array}$ \\
\hline $\begin{array}{c}\text { (Laila \& } \\
\text { Widihadnanto, } \\
\text { 2017) }\end{array}$ & $\begin{array}{l}\text { Altman Z- } \\
\text { Score }\end{array}$ & $\begin{array}{l}2011- \\
2014\end{array}$ & $\begin{array}{c}4 \text { Islamic, } 10 \\
\text { Conventional } \\
\text { Banks }\end{array}$ & Nil & Indonesia & 6 & $\mathrm{NIL}$ & $\begin{array}{l}\text { The model } \\
\text { equally robust } \\
\text { for both } \\
\text { conventional } \\
\text { and Islamic } \\
\text { banks. }\end{array}$ \\
\hline $\begin{array}{l}\text { (Wanke, Azad, } \\
\text { \& Barros, 2016) }\end{array}$ & $\begin{array}{l}\text { Dynamic } \\
\text { Slacks } \\
\text { Based } \\
\text { Model }\end{array}$ & $\begin{array}{l}2009- \\
2013\end{array}$ & $\begin{array}{c}27 \\
\text { Conventional } \\
\text { Banks, } 16 \\
\text { Islamic Banks }\end{array}$ & Nil & Malaysia & 6 & $\mathrm{NI}$ & $\begin{array}{l}\text { Higher } \\
\text { inefficiency } \\
\text { levels and } \\
\text { slacks in } \\
\text { Islamic banks } \\
\text { than the } \\
\text { conventional } \\
\text { ones. }\end{array}$ \\
\hline
\end{tabular}


2000; Haldane, 2012; Khan, 2016; Pappas et al., 2016). The purpose is to use the identified significant indicators as early warning signal for taking timely corrective action so that possibility of complete failure of the bank can be avoided and interest of depositors, investment account holders and other stakeholders can be safeguarded.

Logistic (or logit) regression is used for analysing a data set in which one or more explanatory variables determine the outcome which is measured as a dichotomous variable i.e. where there are only two possible outcomes. Thus, it offers a bet fit model to describe the relationship between the dichotomous variable of interest and as set of independent variables. In this way, it generates the coefficients of formula to predict a logistic transformation of the probability of presence of dichotomous variable of interest. Unlike the ordinary regression, where objective is to find parameters that minimise standard (sum of squared) errors, logit regression estimates find parameters that maximize the likelihood of observing the sample values.

A logit regression expression can be stated as:

$\operatorname{logit}(p)=\beta_{0}+\beta_{1} x_{1}+\beta_{2} X_{2}++\beta 3_{2} X_{3}+\ldots+b_{i} x_{i}$

where $p$ is the probability of presence of the interest variable.

The logit transformation can be defined as logged odds:

Odds $=p /(1-p)$ i.e. probability of the presence of interest variable / probability of the absence of interest variable.
Thus, logit expression can be mentioned as:

$\operatorname{logit}(p)=\ln (p /(1-p))=\beta_{0}+\beta_{1} X_{1}+\beta_{2} X_{2}++\beta_{3} X_{3}+\ldots+b_{i} X_{i}$

The starting hypothesis will be that distress in Islamic banks can be correctly predicted using CAMELS indicators as predictors in a logit regression model.

$D=\beta_{0}+\beta_{C} X_{C}+\beta_{A} X_{A}++\beta_{M} X_{M}+\beta_{E} X_{E}+\beta_{L} X_{L}+\beta_{S} X_{S}+u$

Where $D$ denotes bank distress or failure, and explanatory variable $X$ refers to respective CAMELS indicators as explained in the Table below.

It is worth mentioning that almost none of the literature referred in section 2.4 and 2.5 has covered the last component related to $S$. In this paper, this indicator has been included and defined as: total securities to total assets.

It is expected that decline in capital, earning and liquidity measures will result in potential financial distress in the bank, hence a negative sign is expected. Similarly, increase in NPF, management cost and sensitivity indicators will be an indication of potential difficulties, leading to a positive sign.

In order to test the logit model, defining the criteria for bank distress is important. As stated in the earlier section, absolute failure of Islamic banks is rare. In the advanced economies, failure of small to mid-sized banks is not a major event since small depositors are taken care of by the deposit insurance providers and failure of weaker bank is considered beneficial in the wider interest of competitiveness and market economy. In the emerging markets, on the other hand, regulatory

Table 2: The Description of CAMELS Variables

\begin{tabular}{|c|c|c|}
\hline Explanatory Variable & Description & Formula \\
\hline \hline C (Capital) & Basel risk-weighted Capital Adequacy ratio & Total capital to total risk weighted assets(RWA) \\
\hline A (Asset Quality) & Non-Performing Financing (NPF) & NPF to total financing \\
\hline M (Management) & Efficiency Measure & $\begin{array}{c}\text { Cost to Income Ratio }= \\
\text { operating costs (administrative and fixed costs, } \\
\text { such as salaries and property expenses, but not } \\
\text { bad debts that have been written off) divided by } \\
\text { operating income }\end{array}$ \\
\hline E (Earning) & Income & $\begin{array}{c}\text { Net Operating Income (before depreciation) to } \\
\text { Assets }\end{array}$ \\
\hline L (Liquidity) & Liquid Assets & $\begin{array}{c}\text { Investment in securities, cash and placements } \\
\text { with other banks to total assets }\end{array}$ \\
\hline S (Sensitivity to Market Risk) & $\begin{array}{c}\text { Multiple factors, including profit rate risk, } \\
\text { commodity risk, equity risk and foreign } \\
\text { exchange risk }\end{array}$ & $\begin{array}{c}\text { Rate sensitive liabilities (Securities) to total assets } \\
\text { (S) }\end{array}$ \\
\hline
\end{tabular}


authorities make an effort to take necessary actions to keep the going concern status of the banks, to the extent possible. Sometimes, stronger banks are encouraged to take over the weaker banks or get merged. Similarly, sometimes governments and regulators intervene to rescue the failing banks by putting deposits, changing bank management or putting temporarily under supervisor's control. Therefore, it is in order to use the criteria of bank distress adopted by (Haldane, 2012; Pappas et al., 2016) for considering a bank in distress: An Islamic banks is considered in distress if any of the following criteria is met:

i. negative net worth;

ii. has gone into bankruptcy, dissolution or liquidation;

iii. has been put under supervisor's control or has required government's financial support; and

iv. acquisition by another bank or merger into another bank.

In addition, two more criteria are added related to capital adequacy ratio of sample Islamic banks:

v. risk-weighted capital adequacy is below minimum requirement of $10 \%$; and

vi. tier 1 capital is less than $8 \%$.

These two ratios are added in consideration of the fact that regulators in many sample countries, especially in GCC, require their banks to follow relatively higher capital adequacy ratios than those suggested by the BCBS. A low CAR is also a reflection of bank's impending problems related to management, asset quality, liquidity, profitability or other key dimensions of its operations.

\subsection{Additional Supervisory Parameters and Macroeconomic Variables}

In section 2.1 and 2.2, the paper referred to the evolution of supervisory parameters for bank regulation and the importance given to two primary ratios in Basel III framework, namely risk weighted CAR and non-risk weighted leverage ratio. In addition to these two primary measures, some other literature have suggested a number of other indicators which, in their analysis, are better measures of gauging bank strength and predicting bank distress more effectively. These ratios include:
- Gross Revenue Ratio: (Estrella et al., 2000) suggested the use of this ratio much earlier than the financial crisis. Taking a data of bank failures in US for five years (1988-1992), the paper found this ratio equally robust in predicting bank distress as risk weighted CAR, though the former is simpler, easy to calculate from financial reports and cheaper to supervise. Moreover, since this ratio is less correlated with other regulatory ratios on capital, it offers less room for regulatory arbitrage by the banks. This ratio is, however, risk sensitive only to the extent that risker projects will have higher expected revenues. The shortcoming of this ratio is that banks involved in fee-based activities will have higher gross revenues. The ratio is also more closely linked to business cycles than the CAR.

- $\quad$ Tangible common equity ratio (TCE): (Buehler et al., 2010) found this ratio more effective in predicting bank distress thank other capital ratios, including leverage ratio. Since TCE deducts goodwill, preferred shares, and other intangibles from shareholders' equity, this ratio offers a stringent measure than Tier 1 capital because the latter includes the intangibles. Similarly, this ratio ensures that equity capital is available to absorb losses even that bank is not a going concern since bank have an option to either not make dividend payments entirely or to defer them until a later date.

- $\quad$ Tier 1 ratio: (Haldane, 2012; Merrouche et al., 2010) has tested this ratio, along with CAR and found it equally affective in measuring bank strength.

- $\quad$ Base Risk Weight: (Kellermann \& Schlag, 2013) studied the relative effectiveness of CAR and leverage ratio for Swiss banks and found that application of these two ratios simultaneously, as proposed by BCBS, could motivate the banks to take higher risk as leverage ratio becomes a "binding capital requirement". Therefore, they suggest the introduction of this new ratio that is calculated as risk weighted assets to total onand off-balance sheet assets. The paper highlights that proposed ratio helps resolve this unintended consequence of applying both ratios at a time, is simple to calculate and maintains the risk sensitivity element.

In addition to these six alternative capital ratios, the study will also consider three other leverage ratios: 
Table 3: The Definitions of Alternative Capital and Leverage Ratios

\begin{tabular}{|c|c|c|}
\hline & Capital/Leverage Ratio & Definition \\
\hline 1 & Basel Tier 1 ratio & Tier 1 capital to total RWA \\
\hline 2 & Tangible common equity ratio & Shareholders equity, less goodwill, and other intangibles to RWA \\
\hline 3 & Book leverage ratio & 1- (book value of equity / book value of assets) \\
\hline 4 & Basel leverage ratio & Tier 1 Capital to Exposure (on balance sheet + off balance sheet) \\
\hline 5 & Market leverage ratio & $\begin{array}{c}\text { 1- (market value of equity (=number of shares * end of year stock price) / market value of } \\
\text { bank (=market value of equity + book value of liabilities) }\end{array}$ \\
\hline 6 & Islamic banking leverage ratio & 1- [(book value of equity + book value of PSIA) / book value of assets $]$ \\
\hline 7 & Gross revenue ratio & $\begin{array}{l}\text { Tier } 1 \text { Capital to (total financing, non-financing income and fee based income before the } \\
\text { deduction of any expenses). }\end{array}$ \\
\hline 8 & Base risk weight ratio & RWA to Total Exposure (on balance sheet + off balance sheet) \\
\hline
\end{tabular}

book leverage, market leverage and a newly proposed ratio called 'Islamic banking leverage'. Book leverage is based on accounting data and serves similar purpose as Basel leverage ratio, though it does not include offbalance sheet items. Market leverage, on the other hand, relies on stock market information and therefore can be only investigated for publicly listed banks. Due to its very nature, it is considered forward looking (Barclay, Morellec, and Smith, 2006) and has more managerial importance (Welch, 2004). The paper also adopts definition of 'Islamic banking leverage' from (Khokher \& Alhabshi, 2018) which considers the contractual feature of PSIA offered by Islamic banks according to which these account holders are expected to share the losses incurred on the assets funded by them. If this expectation is true, PSIA should be considered part of the equity and definition of leverage to be modified accordingly.

Based on the aforementioned alternative definitions of capital and leverage, the previous model will be tested by changing CAR with following ratios with the hypothesis that there no differences in the ability of logit model to predict Islamic bank distress using alternative capital adequacy ratios. A variety of capital ratio will help suggest whether simpler ratios perform better than more complex, risk weighted measures in predicting distress in Islamic banks as suggested by (Haldane, 2012).
Finally, three macroeconomic variables: GDP growth, current account and credit (credit-to-GDP ratio) will be added to model as suggested by (Haldane, 2012) with the hypothesis that there is no difference in the ability of logit model to predict Islamic bank distress with additional macroeconomic variables.

\subsection{Description of Data}

This study takes a panel of 65 Islamic banks from 13 countries between 2008-2017, representing all the key regions where Islamic banking is being offered, that includes: Bahrain, Egypt, Jordan, Kuwait, Palestine, Qatar, Saudi Arabia and UAE in the Middle East and North Africa region; Bangladesh and Pakistan from South Asia; Indonesia and Malaysia from Southeast Asia and Turkey from Europe. The sample includes 34 Islamic banks that are publicly listed whereas remaining are unlisted. A large ratio of publicly traded Islamic banks will help to study the impact of market-based leverage indicator. This study focuses on Islamic commercial banks that are either full-fledged banks or independent subsidiaries of conventional banks. Thus, Islamic investment banks and Islamic windows of conventional banks are excluded due to the nature of data required for analysis purposes.

Data for the calculation of market leverage, book leverage, market value of equity, market value of assets, Basel CAR, asset quality, earnings, tangible

Table 4: The Definitions of Alternative Capital and Leverage Ratio

\begin{tabular}{|c|c|c|}
\hline 1 & GDP & Gross Domestic Product Growth \\
\hline 2 & Current account & $\begin{array}{c}\text { Sum of the balance of trade (goods and services export less imports), net income } \\
\text { from abroad and net current transfers }\end{array}$ \\
\hline 3 & Credit & Total credit to the private non-financial sector \\
\hline
\end{tabular}


common equity, Basel Tier 1 ratio and gross revenue ratio for listed Islamic banks were mostly extracted from Thomson Reuters' DataStream and other missing information were gathered from Fitch Connect and annual reports of the Islamic banks directly. However, the calculation of the above-mentioned indicators for non-listed banks were mainly based on data from Thomson Reuters' Eikon and complemented with data from Fitch Connect and individual financial reports. To calculate Islamic banking leverage, data for total unrestricted PSIA were mainly taken from annual reports and published financial statements of Islamic banks. Off balance sheet items were mainly taken from Fitch Connect and annual reports. Moreover, data for economic indicators such as GDP growth and current account were taken from the World Bank's World Development Indicators and Fitch Connect. On the other hand, total credit to the private non-financial sector data were taken from the Bank for International Settlements.

\section{EMPIRICAL ANALYSIS}

This paper uses trans-national panel data from some of the selected countries. Based on the table, the highest number of Islamic banks is from Malaysia (15 banks), followed by Bahrain (7), Indonesia (6) and UAE (6). Out of 65 banks, 8 banks are considered distressed banks based on the criteria defined in the previous section.

Descriptive statistics of the variables used in the analysis shows that mean capital adequacy is much higher $(19.64 \%)$ than the regulatory capital requirement of $8 \%$ or $10 \%$, though with high dispersion. Mean earning is modest whereas liquidity is generally ample. Mean Tier 1 capital and tangible common equity ratios are close to overall CAR, showing the reliance of Islamic banks on more equity than debt. It is in contrast to large conventional banks, where most of the capital is raised through debt based, Tier 2, instruments as reported by (Acharya et al., 2011).

While multicollinearity is one of the main issues in panel data analysis, Variance Inflation Factors (VIF) and pairwise correlation is undertaken to check the presence of multicollinearity. According to (O'Brien, 2007), the VIF value should not exceed 10, however, in this case the maximum VIF is 1.48 for GDP growth. Similarly, the pairwise correlation reported in Table below also shows that there is no presence of multicollinearity as the value of pairwise correlation does not exceed 0.80 (Kennedy, 2008). Hence, the analysis are free from multicollinearity issue.

Based on the first hypothesis, the study estimated a logit model by incorporating bank distress (dependent variable) and CAMELS indicators (independent variables) to examine whether these indicators could correctly predict the failure/ distress of Islamic banks. To evaluate the goodness-of-fit of logistic models, pseudo $R^{2}$ is used in line with other studies on logit regression. In addition, to understand the overall fitness of the model, the study referred to likelihood ratio (LR) $\mathrm{Chi}^{2}$ test. Based on the overall results, the model fitness is good as $\mathrm{Chi}^{2}$ is found to be significant at $1 \%$

Table 5: List of Countries and Bank Description

\begin{tabular}{|c|c|c|c|c|}
\hline Country & Number of Banks & Listed Bank & Non-listed Bank & Distressed Banks \\
\hline Bahrain & 7 & 5 & 2 & 0 \\
\hline Bangladesh & 4 & 4 & 0 & 2 \\
\hline Egypt & 3 & 2 & 1 & 0 \\
\hline Indonesia & 7 & 1 & 6 & 1 \\
\hline Jordan & 2 & 1 & 1 & 0 \\
\hline Kuwait & 4 & 4 & 0 & 0 \\
\hline Malaysia & 15 & 1 & 14 & 3 \\
\hline Pakistan & 4 & 2 & 2 & 1 \\
\hline Palestine & 1 & 1 & 0 & 0 \\
\hline Qatar & 4 & 3 & 1 & 0 \\
\hline Saudi & 4 & 4 & 0 & 0 \\
\hline Turkey & 4 & 1 & 3 & 1 \\
\hline UAE & 6 & 5 & 1 & 0 \\
\hline Total & 65 & 34 & 31 & 8 \\
\hline
\end{tabular}


Table 7: Variance Inflation Factors

\begin{tabular}{|c|c|c|c|c|}
\hline Variable & VIF & SQRT VIF & Tolerance & R-Squared \\
\hline \hline C & 1.0500 & 1.0300 & 0.9495 & 0.0505 \\
\hline A & 1.0500 & 1.0200 & 0.9538 & 0.0462 \\
\hline M & 1.0900 & 1.0400 & 0.9214 & 0.0786 \\
\hline E & 1.0800 & 1.0400 & 0.9262 & 0.0738 \\
\hline L & 1.3400 & 1.1600 & 0.7452 & 0.2548 \\
\hline S & 1.4500 & 1.2100 & 0.6885 & 0.3115 \\
\hline GDP & 1.1400 & 1.0700 & 0.8738 & 0.1262 \\
\hline CA & 1.4800 & 1.2100 & 0.6778 & 0.3222 \\
\hline CREDIT & 1.2900 & 1.1400 & 0.7745 & 0.2255 \\
\hline Mean VIF & 1.2200 & & & \\
\hline
\end{tabular}

Table 8: Pairwise Correlation among main Independent Variables

\begin{tabular}{|c|c|c|c|c|c|c|c|c|c|}
\hline & C & A & $\mathbf{M}$ & E & $\mathbf{L}$ & $\mathbf{S}$ & GDP & CA & CREDIT \\
\hline$C$ & 1 & & & & & & & & \\
\hline A & -0.0043 & 1 & & & & & & & \\
\hline$M$ & 0.0557 & 0.0699 & 1 & & & & & & \\
\hline$E$ & -0.0031 & -0.1418 & -0.1101 & 1 & & & & & \\
\hline$L$ & -0.0189 & 0.1324 & -0.0377 & -0.0462 & 1 & & & & \\
\hline$S$ & -0.0154 & 0.0878 & -0.0165 & -0.0589 & 0.2638 & 1 & & & \\
\hline GDP & -0.0148 & 0.0152 & -0.0352 & 0.0638 & 0.0198 & -0.0005 & 1 & & \\
\hline $\mathrm{CA}$ & 0.1806 & -0.1248 & -0.0014 & -0.0992 & -0.1178 & -0.0021 & 0.2568 & 1 & \\
\hline CREDIT & -0.0197 & 0.0961 & -0.1418 & -0.1027 & 0.1365 & -0.0156 & -0.2431 & -0.3936 & 1 \\
\hline
\end{tabular}

level and the Pseudo $\mathrm{R}^{2}$ is $31 \%$. For this model the total number of observations is 622 .

The results exhibit that out of six potential determinants as per CAMELS framework, four indicators Basel CAR (C), management efficiency (M), liquidity (L) and sensitivity to risk (S) are significant. All the significant indicators have expected signs. The high coefficient of $\mathrm{C}$ shows its strong predictive power on the log-odds of Islamic bank distress.

After estimating the logit regression, the study also estimated conventional goodness of fit test to check the robustness of the results. In line with this, the study estimated Hosmer-Lemeshow $\mathrm{Chi}^{2}$ and Pearson $\mathrm{Chi}^{2}$, and their results are reported in the table below. As highlighted by (Abduh, 2014), Hosmer-Lemeshow test serves similar purpose as F-test in ANOVA, and measures overall goodness of fit for the overall model. Both these tests suggested that the findings of the logit models are robust since the study found both the Hosmer-Lemeshow $\mathrm{Chi}^{2}$ and Pearson $\mathrm{Chi}^{2}$ are statistically significant at $5 \%$ and $1 \%$ levels respectively.
Table 9: Predicting Islamic Bank Distress Using CAMELS Indicators

\begin{tabular}{|c|c|}
\hline & Dependent Variable: D \\
\hline \hline C & $-33.2446^{* * *}$ \\
& $(7.9484)$ \\
\hline M & -4.2079 \\
& $(6.5835)$ \\
\hline E & $0.8095^{*}$ \\
& $(0.4310)$ \\
\hline L & -0.5644 \\
& $(7.5515)$ \\
\hline S & $-3.5407^{*}$ \\
& $(1.8246)$ \\
\hline Cons & $0.0241^{* * *}$ \\
& $(0.0084)$ \\
\hline$N$ & 1.5707 \\
\hline chi ${ }^{2}$ & $(1.1356)$ \\
\hline Pseudo ${ }^{2}$ & 622 \\
\hline $0<05 * 0.01 .8800^{* * *}$ \\
\hline
\end{tabular}

$" p<0.10, " p<0.05, "{ }^{\prime \prime *} p<0.01$.

Equation: $D=\beta_{0}+\beta_{C} X_{C}+\beta_{A} X_{A}++\beta_{M} X_{M}+\beta_{E} X_{E}+\beta_{L} X_{L}+\beta_{S} X_{S}+u$. 
Table 10: Goodness of Fit Test

\begin{tabular}{|c|c|}
\hline Number of observations & 622 \\
\hline Number of groups & 10 \\
\hline Hosmer-Lemeshow chi2 & $18.17^{* *}$ \\
\hline Pearson chi ${ }^{2}$ & $948.96^{* * *}$ \\
\hline
\end{tabular}

$" p<0.10, " p<0.05, "{ }^{* * *} p<0.01$.

The study further tests the sample predictive power for the estimated model by using the linear prediction technique is used with a cut-off point at $50 \%$ similar with the previous study of (Mayes \& Stremmel, 2012). All predictions with a value over $50 \%$ are considered as correctly predicting failures. Based on the results reported below, we can classify $97 \%$ of distress in Islamic banks correctly based on logit technique used in the study. Since the estimated model did not detected any bank failure, hence the study has sufficient confidence that there are no type II errors.

Table 11: Prediction Accuracy (Logit Model)

\begin{tabular}{|c|c|}
\hline \multicolumn{2}{|c|}{ Bank Distress } \\
\hline Correctly Detected & Falsely Detected \\
\hline \hline $97.27 \%$ & - \\
\hline
\end{tabular}

In the next part, the paper focuses on the significance of alternative capital ratios hypothesising that there are no differences in the ability of alternative capital and leverage indicators to predict Islamic bank distress. These variables are: Basel tier 1 ratio (TIER1CAPITAL), tangible common equity ratio (TANGIBLE), book leverage ratio (Lb), Basel leverage ratio $(B I)$, market leverage ratio $(L m)$, Islamic banking leverage ratio $(\mathrm{Li})$, gross revenue ratio (GROSSREV) and Base risk weight ratio (RISKWEIGHT). Each of these variables are separately included in the regression along with CAMELS (except $C$ ) and reported in the Table below. It can be observed that the overall fitness of the models is pretty good as the $\mathrm{Chi}^{2}$ is significant for all the models at $1 \%$ level. The Pseudo $\mathrm{R}^{2}$ is highest when market leverage is used as capital indicator followed by Tier 1 capital and tangible common equity ratios. In all three cases, Pseudo $R^{2}$ is higher than the base model with Basel CAR taken as capital ratio. These three capital indicators also significant and negatively signed as expected. The significance of market leverage shows that market based indicators are relevant for studying the robustness in Islamic banks and predicting their distress, which has not been considered in past studies on Islamic banks.
For other indicators, liquidity and sensitivity to risk are significant in all the models tested which shows the importance of these two determinants in bank distress. More importantly, the coefficient of liquidity is quite high, especially for market leverage specification, which shows that along with capital ratio, problems in liquidity are the major factor that be linked to bank distress. This is plausible since Islamic banks continued to be plagued by the low supply of high quality Shari'ah complaint liquid assets, with lack of secondary markets and lender of last resort facilities by the central banks. (IFSB, 2016; Said, 2011).

Another significant finding of this result is that Basel leverage ratio is not significant, which is in contrast to several studies undertaken for larges sized conventional banks, some of which are quoted in the literature review section. Nevertheless, the results are consistent with the findings of (Haldane, 2012) who found that leverage ratio is not significant for small sized, inter-state banks in US whereas it is significant for large, internationally active US banks. As Islamic banks are generally small and operate at local or regional level, this result is consistent. Similar, is the case of book leverage and Islamic banking leverage indicators. From these results, we can draw the conclusion that simpler, accounting based ratios are not relevant for predicting bank distress in Islamic banks. One possible explanation could be that the leverage in Islamic banks is generally lower than conventional banks, whereas the limit prescribed by the Basel leverage ratio was mainly based on lower common equity in the capital of large conventional banks. Similarly, since Islamic banks have low Tier 2 based debt capital, in practical sense, CAR, Tier 1 ratio and tangible common equity are not drastically different with each other.

After using these alternative capital adequacy ratios in the logit models, the study then checks their robustness by conducting several robustness checks as performed in the previous tables. It was found that Hosmer-Lemeshow $\mathrm{chi}^{2}$ and Pearson $\mathrm{Chi}^{2}$ are both significant for Tier 1 capital, tangible common equity and book leverage. A somewhat surprising result is experienced for market leverage, which is not significant in either of the tests.

While checking for prediction accuracy, the results seem promising. None of the models was falsely detected; similarly, above $96 \%$ of the models are correctly specified based on the relevant test reported in the table below. 
Table 12: Predict Islamic Bank Distress Using Alternative Capital Adequacy Ratios

\begin{tabular}{|c|c|c|c|c|c|c|c|c|}
\hline & \multicolumn{8}{|c|}{ Dependent Variable: D } \\
\hline TIER1CAPITAL & $\begin{array}{c}- \\
30.2574 \\
(5.6503)\end{array}$ & & & & & & & \\
\hline TANGIBLE & & $\begin{array}{c}- \\
25.8733^{* * * *} \\
(6.5192)\end{array}$ & & & & & & \\
\hline Lb & & & $\begin{array}{c}6.3404 \\
(4.5512)\end{array}$ & & & & & \\
\hline $\mathrm{BI}$ & & & & $\begin{array}{c}-0.0109 \\
(0.1445)\end{array}$ & & & & \\
\hline $\mathrm{Lm}$ & & & & & $\begin{array}{c}-10.6318^{* * * *} \\
(4.1064)\end{array}$ & & & \\
\hline $\mathrm{Li}$ & & & & & & $\begin{array}{c}1.9658 \\
(1.5659)\end{array}$ & & \\
\hline GROSSREV & & & & & & & $\begin{array}{l}-0.1188 \\
(0.0966)\end{array}$ & \\
\hline RISKWEIGHT & & & & & & & & $\begin{array}{l}-0.0037 \\
(0.0144)\end{array}$ \\
\hline A & $\begin{array}{r}-13.0613 \\
(8.0876)\end{array}$ & $\begin{array}{c}- \\
17.6544 \\
(8.2632)\end{array}$ & $\begin{array}{l}-7.7559 \\
(6.5924)\end{array}$ & $\begin{array}{l}-7.9447 \\
(6.5635)\end{array}$ & $\begin{array}{c}-5.4559 \\
(12.7195)\end{array}$ & $\begin{array}{c}-5.5272 \\
(6.6997)\end{array}$ & $\begin{array}{r}-10.0665 \\
(7.3848)\end{array}$ & $\begin{array}{c}-8.1014 \\
(6.6016)\end{array}$ \\
\hline M & $\begin{array}{l}0.9935^{* *} \\
(0.4808)\end{array}$ & $\begin{array}{c}0.7058 \\
(0.5338)\end{array}$ & $\begin{array}{c}0.2845 \\
(0.3978)\end{array}$ & $\begin{array}{c}0.0461 \\
(0.3224)\end{array}$ & $\begin{array}{c}0.0249 \\
(0.7910)\end{array}$ & $\begin{array}{c}0.1676 \\
(0.3168)\end{array}$ & $\begin{array}{c}0.1362 \\
(0.4234)\end{array}$ & $\begin{array}{c}0.0475 \\
(0.3203)\end{array}$ \\
\hline $\mathrm{E}$ & $\begin{array}{c}1.1566 \\
(7.4979)\end{array}$ & $\begin{array}{c}-2.2492 \\
(7.4185)\end{array}$ & $\begin{array}{l}-4.2434 \\
(8.8719)\end{array}$ & $\begin{array}{c}-6.2312 \\
(9.4367)\end{array}$ & $\begin{array}{c}-0.6629 \\
(23.4064)\end{array}$ & $\begin{array}{l}-0.3114 \\
(9.0485)\end{array}$ & $\begin{array}{c}-17.0774 \\
(11.2207)\end{array}$ & $\begin{array}{c}-6.2841 \\
(9.4418)\end{array}$ \\
\hline $\mathrm{L}$ & $\begin{array}{c}-4.0025^{* *} \\
(1.8617)\end{array}$ & $\begin{array}{l}-4.0127^{\star *} \\
(1.9075)\end{array}$ & $\begin{array}{c}-5.6682^{4 * *} \\
(1.8638)\end{array}$ & $\begin{array}{c}-5.3909 \\
(1.8606)\end{array}$ & $\begin{array}{c}-12.1619 \\
(4.3494)\end{array}$ & $\begin{array}{c}-4.9860 \\
(1.8975)\end{array}$ & $\begin{array}{l}-4.8332 \\
(2.0323)\end{array}$ & $\begin{array}{l}-5.3764^{* * *} \\
(1.8560)\end{array}$ \\
\hline S & $\begin{array}{l}0.0320 \\
(0.0077)\end{array}$ & $\begin{array}{l}0.0317^{* * *} \\
(0.0085)\end{array}$ & $\begin{array}{l}0.0326 \\
(0.0072)\end{array}$ & $\begin{array}{l}0.0353^{\text {tat }} \\
(0.0071)\end{array}$ & $\begin{array}{l}0.0675^{* * *} \\
(0.0176)\end{array}$ & $\begin{array}{l}0.0352^{4 * *+} \\
(0.0079)\end{array}$ & $\begin{array}{l}0.0428 \\
(0.0082)\end{array}$ & $\begin{array}{l}0.0353^{*+*} \\
(0.0071)\end{array}$ \\
\hline CONS & $\begin{array}{c}0.2292 \\
(0.6676)\end{array}$ & $\begin{array}{c}0.4725 \\
(0.7952)\end{array}$ & $\begin{array}{l}-8.1796 \\
(4.2594)\end{array}$ & $\begin{array}{c}-2.3964 \\
(0.5276)\end{array}$ & $\begin{array}{c}-0.4174 \\
(1.0661)\end{array}$ & $\begin{array}{c}-4.3631^{* * *} \\
(1.5311)\end{array}$ & $\begin{array}{c}-2.3058^{* * * *} \\
(0.6394)\end{array}$ & $\begin{array}{c}-2.3862 \\
(0.5285)\end{array}$ \\
\hline$N$ & 624 & 607 & 625 & 625 & 344 & 608 & 592 & 625 \\
\hline $\mathrm{Chi}^{2}$ & $69.7400^{* * *}$ & $62.07^{* * * *}$ & $36.20^{\star \star * *}$ & $33.52^{* * * *}$ & $63.86^{* * * *}$ & $35.95^{* * *}$ & $38.84^{* * *}$ & $33.64^{* * *}$ \\
\hline Pseudo $\mathrm{R}^{2}$ & 0.3540 & 0.3281 & 0.1837 & 0.1701 & 0.5770 & 0.1837 & 0.2221 & 0.1707 \\
\hline
\end{tabular}

" $p<0.10, " p<0.05, "{ }^{* * *} p<0.01$.

Table 13: Goodness of Fit Test (Various Capital Adequacy Measures)

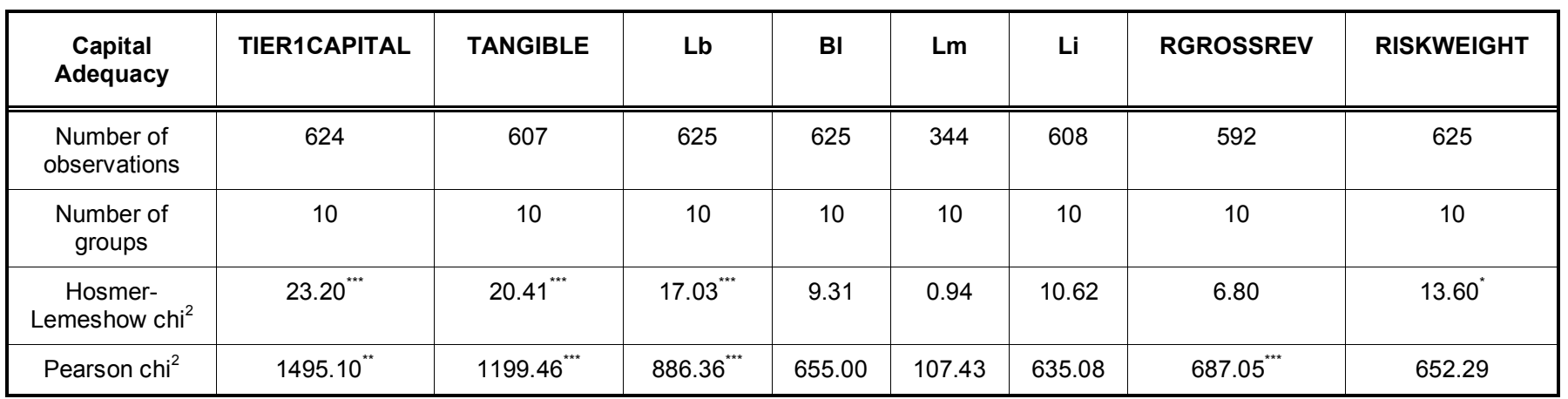


Table 14: Prediction Accuracy (Various Capital Adequacy Measures)

\begin{tabular}{|c|c|c|}
\hline \multirow{2}{*}{ Capital Adequacy } & \multicolumn{2}{|c|}{ Bank Distress } \\
\cline { 2 - 3 } & Correctly Detected & Falsely Detected \\
\hline \hline TIER1CAPITAL & $97.12 \%$ & - \\
\hline TANGIBLE & $96.87 \%$ & - \\
\hline Lb & $96.32 \%$ & - \\
\hline BI & $96.32 \%$ & - \\
\hline Lm & $97.97 \%$ & - \\
\hline Li & $96.22 \%$ & - \\
\hline RGROSSREV & $97.47 \%$ & - \\
\hline RISKWEIGHT & $96.32 \%$ & \\
\hline
\end{tabular}

As a final test, three macroeconomic variables, GDP growth (GDP), current account (CA) and credit (credit-to-GDP ratio) (CREDIT) are also included in the base model to examine the Islamic bank distress. Overall fitness of the model is relatively good as well as the pseudo $\mathrm{R}^{2}$ is also reasonable. However, after adding these macroeconomic variables, the study only found that current account and GDP growth are statistically significant and have negative effect on Islamic bank distress, all other base variables except capital adequacy ratio lose their significance.

The goodness of fit test reported in the table below does not seem to be promising as both of the tests showed insignificant result. However, the prediction accuracy still remains high, above $97 \%$ reported in the table.

Table 15: Goodness of Fit Test

\begin{tabular}{|c|c|}
\hline Number of observations & 279 \\
\hline Number of groups & 10 \\
\hline Hosmer-Lemeshow chi2 & 2.86 \\
\hline Pearson chi & \\
\hline
\end{tabular}

Table 16: Prediction Accuracy (Logit Model)

\begin{tabular}{|c|c|}
\hline \multicolumn{2}{|c|}{ Bank Distress } \\
\hline Correctly Detected & Falsely Detected \\
\hline \hline $97.13 \%$ & - \\
\hline
\end{tabular}

\section{CONCLUSION AND POLICY IMPLICATIONS}

This study uses the data of 65 Islamic banks from 13 key Islamic finance markets, with listed and non- listed banks roughly divided equally. The paper tests six key CAMELS determinants of bank distress in logit regression model, along with eight alternative capital ratios and three macroeconomic variables.

The results of this study are significant from many perspectives and extend the literature on bank distress in emerging markets and Islamic finance in several ways: First, the result delineate that most of the standard CAMELS indicators are relevant for studying distress in Islamic banks. More specifically, risk weighted capital adequacy ratio is significant in analysing resilience in Islamic banks. Second, management quality, liquidity and sensitivity of assets have a clearly identifiable influence. The strong evidence of liquidity on distress in Islamic banks was clearly visible. Similarly, for the first time in any such study on Islamic banks, the findings of this paper show that sixth component of CAMELS, sensitivity to risk is a significant factor and should be considered. Third, based on extensive literature review, eight other alternative ratios are tested, which showed that apart from standard CAR, three other capital ratios are also effective in studying Islamic bank failures. Fourth, market-based leverage, which is tested for the first time in Islamic banking distress literate according to our knowledge, is significant. Fifth, this paper also offers insights on the ongoing debate on the implementation of Basel III leverage ratio on Islamic banks. The results showed that this ratio does not give useful early warning signals for problems in Islamic banks, as probably their leverage is quite low. Finally, it is shown that among the macroeconomic variables, GDP and credit growth exhibit a significant influence, though goodness of fit of this model is not high. Thus, it can be suggested that the base CAMELS models is quite 
significant and offer reliable signals without the addition of macroeconomic variables.

With the increasing size, significance and international expansion of Islamic banks, the stability of individual banks and the financial systems in which they operate is gaining global attention. The "systemically important" market share of this sector in over a dozen important jurisdictions, as stated by the IMF and IFSB in their latest reports ((IFSB, 2016; IMF, 2017; International Monetary Fund, 2018) and the inclusion of this sector in the global financial sector surveillance programme signifies that the development and refinement of early warning parameters for predicting distress in these banks will play a key role not only for bank regulators but also for deposit insurance providers who perform the role of the resolution authority. These findings are also important for governments, policy makers and capital market regulators as liquidity is found to be significant predictor of Islamic bank failure. With the severe shortcomings in liquidity management infrastructure and liquidity support tools available to central banks for Shari'ah compliant banks require a collective effort by key industry stakeholders, including Shari'ah scholars for offering innovative solutions. In this regard, the role of International Islamic Liquidity Management Corporation (IILM) based on Kuala Lumpur needs to be expanded to a wider level from its existing 10 jurisdictions. Similarly, new liquidity requirements proposed by Basel III, called Liquidity Coverage Ratio and Net Stable Funding Ratio can only be effectively implemented by Islamic banks if the aforementioned bottlenecks are resolved. This is also a lesson from the global financial crisis that it is not merely the capital, but liquidity which results in the distress and ultimate bankruptcy of the banks.

The study can be further expanded in several ways. As the objective of this study was to test market leverage, the focus was given to those jurisdictions where consistent market-based data was available. The selection of non-listed banks was also chosen from the same markets. However, there is a room for further extending the data from more jurisdictions. More macroeconomic indicators such as inflation, exchange rate can also be tested in this model. More marketbased data such as earning volatility, stock prices can offer additional insights on the distress prediction of listed Islamic banks. Finally, apart from using logit regression, other estimation techniques such as hazard models and neural networks can offer valuable insights.

\section{REFERENCES}

Abduh, M. (2014). Withdrawal Behavior of Malaysian Islamic Bank Customers: Empirical Evidence from Three Major Issues. Journal of Islamic Banking and Finance, 31(October 2014), 43-54.

Abdul Rahman, R., \& Masngut, M. Y. (2014). The Use Of " CAMELS "In Detecting. The Journal of Applied Business Research, 30(2), 2014. https://doi.org/10.1080/10494820701282447

Abou-El-Sood, H. (2015). Are regulatory capital adequacy ratios good indicators of bank failure? Evidence from US banks. International Review of Financial Analysis. https://doi.org/10.1016/j.irfa.2015.11.011

Acharya, V. V., Gujral, I., Kulkarni, N., \& Hyun Song Shin. (2011). Dividends and bank capital in the financial crisis of 20072009 (NBER Working Paper Series Dividends No. Working Paper 16896). National Bureau of Economic Research Working Paper (VOL. 1). https://doi.org/10.3386/w16896

Acharya, V. V, Mehran, H., \& Thakor, A. (2015). Caught between Scylla and Charybdis? Regulating Bank Leverage When There Is Rent Seeking and Risk Shifting. Review of Corporate Finance Studies, 47. https://doi.org/10.1093/rcfs/cfv006

Admati, A. R. (2016). It Takes a Village to Maintain a Dangerous Financial System (Just Financial Market: Finance in a Just Society, Lisa Herzog, Editor, Oxford University Press, 2016, Forthcoming; Rock Center for Corporate Governance at Stanford University Working Paper No. 219; Stanford University Graduate School of Business Research No. Working Paper No. 3426). Graduate School of Business, Stanford University Working Paper Series. Retrieved from http://ssrn.com/abstract $=2787177$

Admati, A. R., DeMarzo, P. M., Hellwig, M. F., \& Pfleiderer, P (2010). Fallacies, Irrelevant Facts, and Myths in the Discussion of Capital Regulation: Why Bank Equity is Not Expensive. The Rock Center for Corporate Governance at Stanford University Working Paper Series No. Retrieved from http://ssrn.com/abstract=1669704

Admati, A. R., DeMarzo, P. M., Hellwig, M. F., \& Pfleiderer, P. C. (2012). Debt Overhang and Capital Regulation (Rock Center for Corporate Governance at Stanford University Working Paper Series No. 114). Rock Center for Corporate Governance at Stanford University Working Paper Series. https://doi.org/10.2139/ssrn.2031204

Aliyu, S., \& Yusof, R. M. (2017). A panel survival analysis for islamic banks. International Journal of Economics, Management and Accounting, 2(August), 381-410.

Anwar, S., \& Ali, A. M. H. (2018). ANN-Based early warning system for indonesian islamic banks. Bulletin of Monetary Economics and Banking, 20(3), 325-341. https://doi.org/10.21098/bemp.v20i3.856

Atkinson, P., \& Blundell-Wignall, A. (2010). Thinking beyond Basel III. OECD Journal: Financial Market Trends, 2010(1), 9-33. https://doi.org/10.1787/fmt-2010-5km7k9tpcjmn

BCBS. (2010a). An Assessment of the Long-term Economic Impact of Stronger Capital and Liquidity Requirements. Bank for International Settlements. Basel.

BCBS. (2010b). Basel III. Basel III: A global regulatory framework for more resilient banks and banking systems (Vol. 2010). Retrieved from http://www.bis.org/publ/bcbs189.pdf

Beck, T., Demirgüç-kunt, A., \& Merrouchec, O. (2013). Islamic vs . Conventional Banking Business Model, Efficiency and Stability. Journal of Banking \& Finance, 37(2), 433-447. https://doi.org/10.1016/j.jbankfin.2012.09.016

Berger, A. N., DeYoung, R., Flannery, M. J., Lee, D., \& Öztekin, Ö. (2008). How Do Large Banking Organizations Manage Their 
Capital Ratios? Journal of Financial Services Research, 34(2-3), 123-149.

https://doi.org/10.1007/s10693-008-0044-5

Blum, J. M. (2008). Why Basel II May Need a Leverage Ratio Restriction. Journal of Banking \& Finance, 32(8), 1699-1707. https://doi.org/10.1016/j.jbankfin.2007.12.003

Blundell-wignall, A., \& Atkinson, P. (2010). Thinking beyond BASEL III: necessary solutions for capital and liquidity. OECD Journal: Financial Market Trends, 2010(1), 1-23. https://doi.org/10.1787/fmt-2010-5km7k9tpcjmn

Blundell-Wignall, A., \& Caroline Roulet. (2013). Business models OF banks, leverage and the distance-to-default. OECD Journal: Financial Market Trends, Volume 2, 29. https://doi.org/10.1787/fmt-2012-5k4bxlxbd646

Bordeleau, E., Crawford, A., \& Graham, C. (2009). Regulatory Constraints on Bank Leverage: Issues and Lessons from the Canadian Experience (Bank of Canada Discussion Paper 2009-15 No. ISSN 1914-0568). Bank of Canada Discussion Paper 2009-15.

Brei, M., \& Gambacorta, L. (2014). The leverage ratio over the cycle. Bank of International Settlements Working Paper. Basel. Retrieved from http://www.bis.org/publ/work471.htm

Budiman, T., Herwany, A., \& Kristanti, F. T. (2017). An Evaluation of Financial Stress for Islamic Banks in Indonesia Using a Bankometer Model. Journal of Finance and Banking Review, 2(3), 14-20.

Buehler, K. S., J., C. M., \& Samandari, H. H. (2010). A better way to measure bank risk One. McKinsey on Finance.

Chernykh, L., \& Cole, R. a. (2015). How should we measure bank capital adequacy for triggering Prompt Corrective Action? A (simple) proposal. Journal of Financial Stability, 20, 131-143. https://doi.org/10.2139/ssrn.2430300

Čihák, M., \& Hesse, H. (2010). Islamic Banks and Financial Stability: An Empirical Analysis. Journal of Financial Services Research (Vol. 38).

https://doi.org/10.1007/s10693-010-0089-0

D'Hulster, K. (2009, November). Leverage Ratio, A New Binding Limit on Banks. World Bank Crisis Response, 6.

DeAngelo, H., \& Stulz, R. M. (2014). Liquid-claim production, risk management and bank capital structure: Why High leverage is optimal for banks (No. WP 2013-03-08). Fisher College of Business Working Paper Series. Ohio City. Retrieved from http://ssrn.com/abstract=2254998

Demirguc-Kunt, A., Detragiache, E., \& Merrouche, O. (2010). Bank capital: Lessons from the financial crisis. Journal of Money, Credit and Banking, 45(6), 1147-1164. https://doi.org/10.1111/jmcb.12047

Estrella, A., Park, S., \& Peristiani, S. (2000). Capital Ratios as Predictors of Bank Failure. Federal Reserve Bank of New York Economic Policy Review. New York.

Gambacorta, L., \& Karmakar, S. (2016). Leverage and Risk Weighted Capital Requirements (BIS Working Paper Series). BIS Working Papers. Retrieved from http://www.bis.org/publ/work586.pdf

Haldane, G. A. (Bank of E. (2012). The Dog and the Frisbee. In Federal Reserve Bank of Kansas City's 36th economic policy symposium Proceedings, "The Changing Policy Landscape" (p. 37). Jackson Hole, Wyoming. Retrieved from www.bankofengland.co.uk/publications/Pages/speeches/default.aspx

Halteh, K., Kumar, K., \& Gepp, A. (2018). Financial distress prediction of Islamic banks using tree-based stochastic techniques. Managerial Finance, 44(6), 759-773. https://doi.org/10.1108/MF-12-2016-0372

Hasan, M., \& Dridi, J. (2011). The Effects of the Global Crisis on Islamic and Conventional Banks: a Comparative Study. Journal of International Commerce, Economics and Policy, 163(02), 47 Pages.

https://doi.org/10.1142/S1793993311000270
Hildebrand, P. M. (2008). Is Basel II Enough? The Benefits of a Leverage Ratio. In Financial Markets Group Lecture: London School of Economics (p. 14). London: London School of Economics. Retrieved from http://www.bis.org/review/ r081216d.pdf

IFSB. Revised Capital Adequacy Standard (IFSB-15), IFSB 156 (2013).

IFSB. (2015). Islamic Financial Services Industry Stability Report 2015. Kaula Lumpur: Islamic Financial Services Board.

IFSB. (2016). Islamic Financial Services Industry Stability Report 2016. Islamic Financial Services Industry Stability Report Series (Vol. 5). Kuala Lumpur.

IMF. (2017). Ensuring Financial Stability in Countries with Islamic Banking.

International Monetary Fund. (2018). The Core Principles for Islamic Finance Regulations and Assessment Methodology (IMF Policy Paper Series). Staff Report (Vol. 18/193). https://doi.org/10.5089/9781498308496.007

Islamic Financial Services board. (2018). Islamic Financial Services Industry Stability Report 2018. Kuala Lumpur.

Kamada, K., \& Nasu, K. (2010). How Can Leverage Regulations Work for the Stabilization of Financial Systems? (Bank of Japan Working Paper Series How No. 10- E-2). Bank of Japan Working Paper Series. Tokyo. https://doi.org/10.2139/ssrn.1921201

KAZU. (2009). Issues in the International Financial Crisis from an Islamic Perspective (1st ed.). Jeddah: Scientific Publishing Centre, King Abdulaziz University Jeddah I. Retrieved from http://www.kau.edu.sa/Files/121/Researches/55495_25818.p df

Kellermann, K., \& Schlag, C.-H. (2013). Occupy risk weighting: how the minimum leverage ratio dominates capital requirements: A Swiss example. Journal of Financial Regulation and Compliance, 21(4), 353-372. https://doi.org/10.1108/JFRC-06-2012-0019

Khan, U. E. (2016). Bankruptcy Prediction for Financial Sector of Pakistan: Evaluation of Logit and Discriminant Analysis Approaches. Pakistan Journal of Engineering Technology and Science, 6(2), 210-220. https://doi.org/10.22555/pjets.v6i2.1966

Khokher, Z. ur R., \& Alhabshi, S. M. bin S. J. (2018). Capital Structure and Leverage Decisions in Publicly Listed Islamic Banks: What are Key Determinants? In Emerging Issues in Economics and Finance (pp. 1-22).

Kumar, V., \& Sayani, H. (2015). Application of CAMEL model on the GCC Islamic Banks: 2008-2014. Journal of Islamic Banking and Finance, 3(2), 2008-2014. https://doi.org/10.15640/jibf.v3n2a1

Laila, N., \& Widihadnanto, F. (2017). Financial distress prediction using Bankometer model on Islamic and conventional banks: Evidence from Indonesia. International Journal of Economics and Management, 11(Speciallssue1), 169-181.

Mayes, D. G., \& Stremmel, H. (2012). The Effectiveness of Capital Adequacy Measures in Predicting Bank Distress. SUERF Working Paper. https://doi.org/10.2139/ssrn.2191861

Merrouche, A., Detragiache, E., \& Merrouche, O. (2010). Bank Capital: Lessons from the Financial Crisis (Wold Bank Policy Reseach Working Paper Series No. 5473). Wold Bank Policy Reseach Working Paper. https://doi.org/10.5089/9781455210930.001

O'Brien, R. M. (2007). A caution regarding rules of thumb for variance inflation factors. Quality and Quantity, 41(5), 673-690. https://doi.org/10.1007/s11135-006-9018-6

Ojo, M. (2015). Enhancing the reliability of performance measures in empirical based research: leverage ratios and theoretical based research. Munich Personal RePEc Archive. https://doi.org/10.2139/ssrn.2558919 
Pappas, V., Izzeldin, M., \& Fuertes, A. (2016). A Survival Analysis of Islamic and Conventional Banks. Journal of Financial Services Research, (Feb), 1-36. Retrieved from http://link.springer.com/article/10.1007/s10693-016-0239-0

Poghosyan, T., \& Čihák, M. (2011). Distress in European Banks: An Analysis Based on a New Data Set. Journal of Financial Service Research, 40(3), 163-184. https://doi.org/10.1007/s10693-011-0103-1

Said, A. (2011). Does the Use of Sukuk ( Islamic bonds ) Impact Islamic Banks Performances? A Case Study of Relative Performance during 2007-2009. Middle Eastern Finance and Economics, 12(12), 65-76.

Sapuan, N. M., Bakar, S., \& Ramlan, H. (2017). Predicting The Performance And Survival Of Islamic Banks In Malaysia To Achieve Growth Sustainability. SHS Web of Conferences, Volume 14,(1), 48-59. http://doi.org/10.1051/, 00016 (2017) 7360001 SHS Web of Conferences 36 shsconf/201 2016 ICGA 6
Spong, K. (2000). Banking regulation: its purposes, implementation, and effects. Federal Reserve Bank of Kansas City (Fifth Edit). Kansas City: Federal Reserve Bank of Kansas City. http://doi.org/DOI:

Turner, A. (2010). What do banks do? Why do credit booms and busts occur and what can public policy do about it? In The Future of Finance: And the Theory that underpins it (1st ed. pp. 5-86). London: London School of Economics. Retrieved from http://harr123et.files.wordpress.com/2010/07/ futureoffinance-chapter11.pdf

Wanke, P., Azad, M. A. K., \& Barros, C. P. (2016). Financial distress and the Malaysian dual baking system: A dynamic slacks approach. Journal of Banking and Finance, 66, 1-18. https://doi.org/10.1016/j.jbankfin.2016.01.006

Wissén, P. (2010). Consequences of limiting the leverage ratio for banks. Swedish Financial Markets Committee Report. Stockholm.

DOI: https://doi.org/10.6000/1929-7092.2019.08.56

(C) 2019 Khokher and Alhabshi; Licensee Lifescience Global.

This is an open access article licensed under the terms of the Creative Commons Attribution Non-Commercial License (http://creativecommons.org/licenses/by-nc/3.0/) which permits unrestricted, non-commercial use, distribution and reproduction in any medium, provided the work is properly cited. 